\title{
CEBPB Gene
}

National Cancer Institute

\section{Source}

National Cancer Institute. CEBPB Gene. NCI Thesaurus. Code C104116.

This gene plays a role in immune and inflammatory responses. 